\title{
Okul Öncesi Öğretmen Adaylarının Değer Algılarının Çeşitli Değişkenler Açısından İncelenmesi
}

\author{
Burcu Özdemir-Beceren, Zehra Bilgen
}

Temel Ĕ̌itim Bölümü, Ĕ̆itim Fakültesi, Çanakkale Onsekiz Mart Üniversitesi, Çanakkale, Türkiye

Sorumlu Yazar: Burcu Özdemir Beceren, burcubeceren@comu.edu.tr

Makale Türü: Araştırma Makalesi

Bilgilendirme: Bu makale, 27-29 Nisan 2017 tarihinde düzenlenen VII. Uluslararası Eğitim Araştırmaları Kongresi’nde sunulan bildirinin genişletilmesi ile oluşturulmuştur.

Kaynak Gösterimi: Özdemir Beceren, B., \& Bilgen, Z. (2019). Okul öncesi öğretmen adaylarının değer algılarının çeşitli değişkenler açısından incelenmesi. Eğitimde Kuram ve Uygulama, 15(4), 363-379. doi: 10.17244/eku.558989

Investigation of Value Perceptions of Preservice Preschool Teachers in Terms of a Range of Variables Burcu Özdemir-Beceren, Zehra Bilgen

Department of Primary Education, Faculty of Education, Canakkale Onsekiz Mart University, Canakkale, Turkey

Corresponding Author: Burcu Özdemir-Beceren, burcubeceren@comu.edu.tr

Article Type: Research Article

Acknowledgement: This article was generated by expanding the paper presented at the 7th International Educational Research Congress regulated on 27-29 April 2017.

To Cite This Article: Özdemir Beceren, B., \& Bilgen, Z. (2019). Okul öncesi öğretmen adaylarının değer algılarının çeşitli değişkenler açısından incelenmesi. Eğitimde Kuram ve Uygulama, 15(4), 363-379. doi: 10.17244/eku.558989 

2019, 15(4), 363-379

\title{
Okul Öncesi Öğretmen Adaylarının Değer Algılarının Çeşitli Değişkenler Açısından İncelenmesi
}

\author{
Burcu Özdemir-Beceren, Zehra Bilgen \\ Temel Eğitim Bölümü, Eğitim Fakültesi, Çanakkale Onsekiz Mart Üniversitesi, Çanakkale, Türkiye \\ ORCID: https://orcid.org/0000-0003-3680-7511 \\ ORCID: https://orcid.org/0000-0002-4146-3090
}

\begin{tabular}{|c|c|}
\hline Öz & Makale Bilgisi \\
\hline $\begin{array}{l}\text { Araştırmanın amacı, okul öncesi öğretmen adaylarının değer algılarını belirlemektir. } \\
\text { Değer algıları ile cinsiyet, eğitim öğretim görülen sınıf düzeyi ve akademik başarı düzeyi } \\
\text { arasında bir farklılaşmanın olup olmadığını belirlemek araştırmanın alt amaçlarını } \\
\text { oluşturmaktadır. Araştırma nicel araştırma modellerinden tarama modeli kullanılarak } \\
\text { tasarlanmıştır. Çalışma grubunu Türkiye'nin kuzey batı bölgesinde Temel Eğitim Bölümü } \\
\text { Okul Öncesi Eğitimi Anabilim dalında } 2016-2017 \text { eğitim-öğretim yılında eğitim öğretim } \\
\text { gören } 313 \text { okul öncesi öğretmen adayı oluşturmaktadır. Veri toplama aracı olarak } \\
\text { araştırmacı tarafından hazırlanan kişisel bilgi formu ve değer önceliklerini ölçmek } \\
\text { amacıyla Schwartz ve diğerleri (2012) tarafından geliştirilmiş Portre Değerler Anketi } \\
\text { (PDA57) kullanılmıştır. Araştırma sonucunda okul öncesi öğretmen adaylarının en yüksek } \\
\text { değer algı becerisinin iyilikseverlik güvenirlik, en düşük değer algı becerisinin de güç } \\
\text { kaynakları olduğu ortaya çıkmıştır. Okul öncesi öğretmen adaylarının değer alg1 alt } \\
\text { boyutlarından olan kurallara uyma ve kişisel güvenlik alt boyutlarının cinsiyete göre } \\
\text { anlamlı şekilde farklılaştığı sonucuna ulaşılmıştır. Değer algı alt becerilerinden olan } \\
\text { saygınlık, öz yönelim davranış, öz yönelim düşünce, evrenselcilik ilgi, iyilikseverlik, } \\
\text { güvenirlik, iyilikseverlik sevgi ve toplumsal güvenliğin sınıf düzeyine göre anlamlı olarak } \\
\text { farklılaştığı ortaya çıkmıştır. Okul öncesi öğretmen adaylarının değer algı alt } \\
\text { becerilerinden olan başarı, evrenselcilik hoşgörü, iyilikseverlik sevgi, kişilerarası uyum ve } \\
\text { kurallara uyma becerilerinin akademik başarı düzeyine göre anlamlı bir şekilde } \\
\text { farklılaştığı sonucu ortaya çıkmıştır. }\end{array}$ & $\begin{array}{l}\text { Makale Geçmişi: } \\
\text { Geliş: } 29 \text { Nisan } 2019 \\
\text { Düzeltme: } 28 \text { Kasım } 2019 \\
\text { Kabul: } 30 \text { Kasım } 2019 \\
\text { Makale Türü: Araştırma } \\
\text { Makalesi }\end{array}$ \\
\hline
\end{tabular}




\section{Investigation of Value Perceptions of Preservice Preschool Teachers in Terms of a Range of Variables}

\begin{abstract}
The aim of the research was to determine the value perceptions of preschool teacher candidates. The secondary aim of the research was to determine whether value perceptions differed according to gender, year level of education and academic success level. The research was designed using the screening model from the quantitative research models. The study group for the research comprised 313 preservice teachers attending a Department of Primary Education, Preschool Education branch in Turkey's northwest in the 2016-2017 academic year. The personal information form, created by the researchers, and the Portrait Value Questionnaire (PVQ57), developed by Schwartz et al. (2012) to measure value priorities, were used as data collection tools. At the end of the research, preservice preschool teachers had the highest value perception skills for dependable benevolence with the lowest value perception skills for power resources. It was concluded that the value perception subdimensions of rule conformity and personal security of preservice preschool teachers differed significantly according to gender. The value perception subskills of face, self-directed action, self-directed thought, concerned universalism, dependable benevolence, caring benevolence and societal security were revealed to differ according to class level. The value perception subskills of achievement, tolerant universalism, caring benevolence, interpersonal conformity and rule conformity were concluded to differ significantly according to academic success levels among preschool teacher candidates.
\end{abstract}

\section{Article Info}

Keywords: Value perception, Preschool education, Teacher candidate

\section{Article History:}

Received: 29 April 2019

Revised: 28 November 2019

Accepted: 30 November 2019

Article Type: Research Article 


\section{Giriş}

Kültürü oluşturan temel öğelerden biri olan değerler, bir durum ya da olay hakkındaki düşünceleri, tutumları, davranışları ve kararları etkileyerek hayata anlam veren fikir birliğidir (Zevalsiz, 2014). Değer, genel olarak davranışlara rehberlik eden ilkeler ve temel inançlar, yapılan eylemlerin yargılandığı standartlar olarak tanımlanmaktadır (Halstead ve Taylor, 2000). Bir toplumda insanların deneyimlerinin birikimi sonucunda değerler sistemi oluşur (Hoşgörür, 2017). Değerler insanların iyi-kötü, doğru-yanlış, güzel-çirkin gibi tercihler yapmakta kullandıkları ölçütler olmasından dolayı evrensel bir öneme sahiptir (Şişman, 2000). Kişilerin yaşam tarzları benimsedikleri değere göre oluşmakta olup bu değerlerin önem sırasına konularak bir yapı oluşturulması değerler sistemini meydana getirmektedir (Saracaloğlu, Uça, Başara-Baydilek, \& Coşkun, 2013). Düşünce ve eylemlerimizi etkileyerek onlara yön veren ve davranışların temelinde yer alan değerlerin duyuşsal alan içerisinde yer almasından dolayı toplumsal değişimin sağlanması için değerler ve değerler eğitiminin önemi yadsınamaz (Demircioğlu ve Tokdemir,2008). Bu sebeple toplumsal değişimi sağlayacak olan eğitim sistemi o toplumun değerlerini yansitacak önemli bir niteliğe sahip olmalıdır.

Değerler, insanın yaşadığı çevre ve deneyimleri ile yakından ilgilidir. Değerlerin bu kadar geniş bir yelpazede toplanmasından dolayı değerlerin sistemli bir şekilde verilmesi gereklidir. Değerleri anlamak, değerlerin bireysel ve toplumsal olarak nasıl geliştiğini izlemek için araştırmacılar bu konular üzerinde çalışma yapmaktadırlar (Inglehart ve Baker, 2000; Schwartz, 2006). Yapılan bu çalışmalar insani değerlere ilişkin kuramları ortaya çıkarmıştır. İnsani değerler üzerine en etkili kuramlardan birisini Schwartz (1992) geliştirmiştir. Schwartz değerleri, istek uyandıran, duruma göre önemi değişebilen amaçlar olarak açıklamaktadır (Tosun ve Uyanık-Balat, 2017). Schwartz (1994) değerlerin, biyolojik ve sosyal etkileşimde yol gösterici olduğunu, davranışları motive ettiğini, yaşamı yönlendirdiğini, bireylerin toplumda kabul görmelerini sağlayan normlar edinmelerini sağladığını belirtmiştir. Schwartz (1994; 2006) değerlere ilişkin 10 farklı değer tipinin olduğu bir sınıflama yapmış ve bu değerleri yatay ve dikey olmak üzere iki boyutta toplamıştır.

Yatay boyut, Yeniliğe Açıklık/Muhafazacı Yaklaşım olarak isimlendirilmiştir. Yeniliğe açıklık tarafında "özyönelim" ve "uyarılım", muhafazacı yaklaşım tarafında "güvenlik", "uyma" ve "geleneksellik" değerleri yer almaktadır. Yenilikçi alanda yer alan değerler, bireylerin duygusal ve düşünsel yapıları ile ilgili ilişkilerini gerçekleştirmeyi sağlayan değerlerdir. Muhafazakar alanda yer alan değerler, bireyin yakınında olan kişiler, kuruluşlar ve gelenekler ile olan ilişkilerini gerçekleştirir. Dikey boyut, Özgenişletim/Özaşkınlık olarak isimlendirilmiştir. Özgenişletim tarafında "güç" ve "başarı", özaşkınlık tarafında "evrensellik" ve "iyilikseverlik" değerleri bulunmaktadır. Özgeniş̧letim alanında yer alan değerler başkalarına zarar gelecek olsa da, bireyin kendi çıkarları doğrultusunda davranmasını sağlayan değerlerdir. Özaşkınlık tarafında bulunan değerler ise kendine yakın ya da uzak insanlığın ve doğanın yararı için bencillikten uzak kalmayı sağlayacak değerleri içerir. Yeniliğe açıklık ve özgenişletim alanlarında ortak olarak sadece "hazcılık" değer tipi bulunmaktadır (Schwartz, 1994; Schwartz, 2006; Tosun ve Uyanık-Balat, 2017).Değerlere ilişkin yapılan bu modelde yer alan değer türleri arasında uyumluluk ya da uyumsuzluğa dayalı dinamik bir ilişki bulunmaktadır.

Toplumun sosyo-kültürel öğelerine anlam veren değerler, kişilere ya da gruba yararlı ve beğenilen her şeyi içerir (Özensel, 2003). Bundan dolayı değişimin yaşandığı dünyada daha önceden benimsenen mikro değerler yerini küresel değerlere bırakmıştır. Küresel ya da ortak değerler içerisinde yer alan, adalet, hoşgörü, uzlaşma, refah, özgürlük, ahlak, bilgi, düzen, barış ve kalite değerleri önem kazanmaktadır (Yazıcı, 2006). Dünya üzerinde değişen sosyal yapı sonucunda ortaya çıkan problemlerden çocuklarda etkilenmektedir. Bundan dolayı birçok eğitimci bu sorundan kurtulmanın yolunu değerler eğitiminden geçtiğini düşünmektedir. Ortak değerler olarak adlandırdığımız temelin insani değerleri benimseyen hayatlarında bu değerlere bağlı kalan bireyler yetiştirmek aile, okul ve toplumun temel görevi olmalıdır. Eğitim sistemi içerisinde değerlerin aktarılmasına ilişkin okula düşen bu görevde en önemli rol eğitimcilerdedir (Akbaba-Altun, 2003). Değerler bir bütün olarak eğitim sürecinin tüm aşamasında; öğrenme ortamının düzenlenmesinde, etkinliklerin uygulanmasında, öğretim stratejisinin belirlenmesinde, içeriğin oluşturulmasında, sınıf içi davranışlarda, öğretim stilinin seçilmesinde, disiplin uygulamalarında, öğrenciye ilişkin tutum ve davranışlarda bulunmaktadır (Veugelers ve Vedder, 2003; akt: Balcı ve Yanpar-Yelken, 2010). Okul ortamı etkileşimin sağlandığı değerlerin sosyalleştiği bir ortamdır. Öğretmenlerin değer algılarının hayat görüşleri, değer 
öğretimine yönelik stratejileri ve mesleğe ilişkin tutumlarında önemli bir etkisinin olduğu söylenebilir (Balcı ve Yanpar-Yelken, 2010). Bu sebeplerden dolayı eğitim kurumlarında görev alacak olan öğretmen adaylarının nasıl bir kültürlenme ve sosyalleşme süreci içerisinde oldukları belirlenerek onların değer algılarının bilinmesi önemlidir (Sarı, 2005). Öğrencilerin eğitim sürecinde ilk karşılaştıkları ve ailelerinden sonra model aldıkları kişilik ve karakter oluşumunda önemli okul öncesi öğretmenleri önemli bir yere sahiptir. Bundan dolayı gelecekte okul öncesi öğretmenliği yapacak olan okul öncesi öğretmen adaylarının değer algılarının belirlenmesi ve bu değer algılarının evrensel değerlere göre eğitim sürecinde şekillendirilmesi önemlidir. Araştırmanın amacı, okul öncesi öğretmen adaylarının değer algılarını belirlemektir. Bu ana amaç doğrultusunda araştırmanın alt amaçları ise aşağıda yer almaktadır.

Okul öncesi öğretmen adaylarının;

1. Değer algıları nasıldır?

2. Değer algıları cinsiyete göre anlamlı şekilde farklılaşmakta mıdır?

3. Değer algıları eğitim-öğretim gördükleri sınıf düzeyine göre anlamlı şekilde farklılaşmakta mıdır?

4. Değer algıları akademik başarı düzeyine göre anlamlı olarak farklılaşmakta mıdır?

\section{Yöntem}

Araştırmada okul öncesi öğretmen adaylarının değer algılarını belirlemek amaçlandığından betimsel tarama modeli kullanılmıştır. Tarama modeli, daha önceden var olan modelleri, geçmişte olan ve hala varlığını sürdüren bir durumun görüldüğü gibi açıklanması ile açıklanabilecek bir yaklaşımdır (Karasar, 2014). Okul öncesi öğretmen adaylarının değer algılarının ortaya çıkarılacağından araştırmada tarama modeli kullanılmıştır.

\section{Çalışma Grubu}

Araştırmanın çalışma grubunu Türkiye'nin kuzey batı bölgesinde Temel Eğitim Bölümü Okul Öncesi Eğitimi Anabilim dalında 2016-2017 eğitim-öğretim yılında eğitim gören 313 öğretmen adayı oluşturmaktadır. Çalışma grubunda bulunan okul öncesi öğretmen adaylarının demografik özelliklerine ilişkin bilgiler Tablo 1'de yer almaktadır.

Tablo 1: Çalışma grubunu oluşturan öğretmen adaylarının demografik özellikleri

\begin{tabular}{|c|c|c|c|}
\hline & & f & $\%$ \\
\hline \multirow{2}{*}{ Cinsiyet } & Kadın & 276 & 88.20 \\
\hline & Erkek & 37 & 11.80 \\
\hline \multirow{4}{*}{ Eğitim-öğretim gördükleri sınıf düzeyi } & 1. sinif & 89 & 28.40 \\
\hline & 2. sinif & 88 & 28.10 \\
\hline & 3. sinif & 102 & 32.60 \\
\hline & 4. $\sin 1 f$ & 34 & 10.90 \\
\hline \multirow{3}{*}{ Akademik başarı düzeyi } & $2.01-2.50($ düşük $)$ & 114 & 36.40 \\
\hline & $2.51-3.00$ (orta) & 121 & 38.70 \\
\hline & $3.01-3.50$ (yüksek) & 78 & 24.90 \\
\hline
\end{tabular}

Tablo 1'e göre araştırmaya katılan okulöncesi öğretmen adaylarının \%88.2'si kadın, \%11.8'i erkektir. Okul öncesi öğretmen adaylarının sınıf düzeyine göre en yüksek oranın \%32.6 ile "3. sınıfta", akademik başarıya göre ise en yüksek oranın \%38.7 ile 2.51-3.00 aralığında olduğu görülmektedir.

\section{Veri Toplama Araçları}

Araştırmada okul öncesi öğretmen adaylarının değer algılarını çeşitli değişkenler açısından incelemek amacıyla, araştırmacılar tarafından geliştirilen Kişisel Bilgi Formu ile Portre Değerler Anketi (PDA57) kullanılmıştır.

\section{Kişisel Bilgi Formu}

Okul öncesi öğretmen adaylarına araştırma amacında kullanılacak olan demografik özellikleri belirlemek amacıyla, amacıyla öğretmen adaylarına, cinsiyet, öğrenim görülen sınıf düzeyi ve akademik başarı düzeyine ilişkin soruların sorulduğu formdur. 


\section{Portre Değerler Anketi}

Portre Değerler Anketi (PDA 57), katılımcıların değer önceliklerini ölçmek amacıyla Schwartz ve diğerleri (2012) tarafından geliştirilmiş olup anketin yapı geçerliliği farklı kültürlerde görgül olarak ortaya çıkmıştır. Anket, 57 maddeden oluşmakta olup her biri üç maddeden oluşan 19 farklı değer tipinden oluşmaktadır. Ankette, "Saygınlık", "Güç kaynakları", "Güç baskınlığı", "Başarı", "Hazcılık", "Uyarılma”, "Öz yönelim davranış”, "Öz yönelim düşünce", "Evrenselcilik hoşgörü", "Evrenselcilik doğa", "Evrenselcilik ilgi”, "İyilikseverlik güvenirlik", "İyilikseverlik sevgi”, "Alçakgönüllülük", "Kişilerarası uyum”, "Kurallara uyma”, "Geleneksellik", "Toplumsal güvenlik" ve "Kişisel güvenlik" değer tipleri bulunmaktadır. Ankette yer alan her bir madde kişi için belli bir şekilde davranmanın önemini ifade etmeye yarayan cümle portrelerinden oluşmaktadır. Ankette yer alan maddelerden herhangi birine ilişkin "Kurallarl veya düzenlemeleri asla ihlal etmemek onun için önemlidir. "ifadesi örnek olarak verilebilir. Ankette yer alan her bir soruda katılımcılara cevaplaması için altı aralıklı $(1=$ Bana hiç benzemiyor, $2=$ Bana benzemiyor, 3 = Bana çok az benziyor, $4=$ Bana az benziyor, $5=$ Bana benziyor, $6=$ Bana çok benziyor) derecelendirme kullanılmış olup en uygun seçeneğin işaretlenmesi istenmiştir. On dokuz değer tipi için test- tekrar test yöntemi ile güvenirliğe bakılmış olup güvenirlik değerleri .48 ile .81 arasında değişmektedir (Demirutku ve GümüşDirilen, 2014). PDA 57, içerisinde yer alan on dokuz alt boyutun iç tutarlılık katsayısı olan Cronbach Alpha değeri çalışmamızda .68 ile .77 arasında yer almaktadır.

\section{Verilerin Analizi}

Araştırmada verileri analiz etmek için IBM SPSS 24 programı kullanılmıştır. Verilerin analizinde betimsel istatistikten faydalanılmış olup verinin dağılımının parametrik olup olmadığını belirlemek amacıyla analizler yapılmıştır. PDA 57 ölçme aracı içerisinde bulunan on dokuz alt boyutun çarpıklık değerinin -1.37 ile. 10, basıklık değerinin -.63 ile 1.07 arasında olduğu ortaya çıkmıştır. Tabachnick ve Fidell'e (2013) göre basıklık ve çarpıklık değerlerinin -1.5 ile 1.5 aralığında olması koşulu ile dağılımın normal dağılım gösterdiğini söylenebilir. Dağılımın parametrik olmasından dolayı araştırmanın amaçları doğrultusunda kullanılacak olan testler de bu duruma göre seçilmiştir. Fark testlerinde ikili gruplar için T-testi, üç ve daha fazla gruplar için tek yönlü varyans analizi yapılmıştır. Cinsiyet değişkenine göre farklılı̆g varyans analizi yapılmıştır. Tek yönlü varyans analizi sonucunda ortaya çıkan farklılığın hangi gruplardan kaynaklandığını ortaya koymak amacıyla post hoc analizlerden Scheffe testi yapılmıştır. Gruplar arasında yapılan farklılaşma testlerinde anlamlılık düzeyi .05 olarak kabul edilmiştir.

\section{Bulgular}

Araştırmanın alt problemleri doğrultusunda yapılan analizler sonucunda elde edilen bulgular alt problemlere göre aşağıda verilmiştir. Araştırmanın birinci alt problemi olan "Okul öncesi öğretmen adaylarının değer algıları nasıldır?" sorusuna ilişkin olarak elde edilen bulgular Tablo 2'de yer almaktadır.

Tablo 2: Okul öncesi öğretmen adaylarının değer algılarına ilişkin durumları

\begin{tabular}{lcc}
\hline Alt Boyutlar & $\bar{X}$ & Ss \\
\hline Saygınlık & 5.01 & .82 \\
Güç kaynakları & 3.54 & 1.22 \\
Güç baskınlığı & 3.65 & 1.08 \\
Başarı & 4.90 & .74 \\
Hazcılık & 5.20 & .67 \\
Uyarılma & 4.76 & .86 \\
Öz yönelim davranış & 5.33 & .70 \\
Öz yönelim düşünce & 5.22 & .71 \\
Evrenselcilik hoşgörü & 5.09 & .74 \\
Evrenselcilik doğa & 4.98 & .83 \\
Evrenselcilik ilgi & 5.39 & .65 \\
İyilikseverlik güvenirlik & 5.43 & .66 \\
İyilikseverlik sevgi & 5.35 & .67 \\
Alçakgönüllülük & 4.66 & .80
\end{tabular}


Kişilerarası uyum

Kurallara uyma

Geleneksellik

Toplumsal güvenlik

Kişisel güvenlik
4.73

4.20

4.55

5.35

4.95
.86

1.10

1.09

.77

.78

Tablo 2'ye göre okul öncesi öğretmen adaylarının değer algıları incelendiğinde en yüksek ortalamaya sahip değer algı becerisinin 5.43 ile "iyilikseverlik güvenirlik", en düşük ortalamaya sahip değer algısı becerisinin ise 3.54 ile "güç kaynakları" olduğu ortaya çıkmıştır. Ayrıca, "evrenselcilik ilgi", "iyilikseverlik sevgi" ve "toplumsal güvenlik" değer algı becerilerinin de yüksek ortalamaya sahip olduğu, "güç baskınlığı", "kurallara uyma" ve "geleneksellik" değer algı becerilerinin de düşük ortalamaya sahip olduğu belirlenmiştir. Değerler algıları alt boyutlar incelendiğinde genel olarak ortalamanın yüksek olduğu söylenebilir. Okul öncesi öğretmen adayları iyilikseverlik güvenirlik becerisini değer algısında önemli olduğunu, güç kaynaklarının ise çok fazla önemli olmadığını ifade etmişlerdir.

Araştırmanın ikinci alt problemi olan "Okul öncesi öğretmen adaylarının değer algılarının cinsiyete göre anlamlı şekilde farklılaşmakta mıdır?" sorusuna ilişkin olarak yapılan t-testi sonucunda elde edilen bulgular Tablo 3'te yer almaktadır.

Tablo 3: Okul öncesi öğretmen adaylarının değer algılarının cinsiyete göre farklılaşıp farklılaşmadığını belirlemek amacıyla yapılan t-testi sonuçları

\begin{tabular}{|c|c|c|c|c|c|c|c|c|}
\hline & Crunlon $>$ s & $\Delta T$ & $\overline{\mathrm{y}}$ & SC & $\mathrm{Ch}$ & & Testi & \\
\hline & Gruplar & $N$ & $X$ & $\mathrm{SS}$ & $\sin _{\bar{x}}$ & $t$ & $S d$ & $p$ \\
\hline & Kadın & 276 & 5.02 & .83 & .05 & & & \\
\hline Saygınlik & Erkek & 37 & 4.96 & .77 & .12 & .39 & 311 & .69 \\
\hline Güc kavnakları & Kadın & 276 & 3.50 & 1.20 & .07 & & & \\
\hline Güç kaynakları & Erkek & 37 & 3.83 & 1.34 & .22 & -1.55 & 311 & .12 \\
\hline & Kadın & 276 & 3.63 & 1.06 & .06 & & & \\
\hline Güç baskınlığ1 & Erkek & 37 & 3.82 & 1.19 & .19 & -1.03 & 311 & .30 \\
\hline & Kadın & 276 & 4.92 & .73 & .04 & & & \\
\hline Başarı & Erkek & 37 & 4.75 & .81 & .13 & 1.29 & 311 & .19 \\
\hline & Kadın & 276 & 5.22 & .66 & .04 & & & \\
\hline Hazcilik & Erkek & 37 & 5.09 & .75 & .12 & 1.14 & 311 & .25 \\
\hline Uvarılma & Kadın & 276 & 4.76 & .85 & .05 & -13 & 311 & 89 \\
\hline Uyarıima & Erkek & 37 & 4.78 & .93 & .15 & -.13 & 311 & .89 \\
\hline Öz vönelim davranıs & Kadin & 276 & 5.35 & .69 & .04 & & & \\
\hline Zz yonelım davranış & Erkek & 37 & 5.18 & .73 & .12 & 1.43 & 311 & .15 \\
\hline & Kadin & 276 & 5.21 & .71 & .04 & 20 & & \\
\hline Oz yönelim düşünce & Erkek & 37 & 5.24 & .69 & .11 & -.20 & 311 & .83 \\
\hline Eyrenselcilik hosö̈rï & Kadın & 276 & 5.12 & .73 & .04 & & & \\
\hline Evrenseicinik noşgoru & Erkek & 37 & 4.87 & .84 & .13 & 1.92 & 311 & .05 \\
\hline & Kadın & 276 & 5.01 & .80 & .04 & 181 & 311 & \\
\hline Evrenselcllik doga & Erkek & 37 & 4.74 & 1.01 & .16 & 1.81 & 311 & (07 \\
\hline & Kadın & 276 & 5.40 & .63 & .03 & & & \\
\hline Evrenselc1lık 1lg1 & Erkek & 37 & 5.31 & .74 & .12 & .82 & 311 & .41 \\
\hline İyilikseverlik oüvenirlik & Kadin & 276 & 5.46 & .64 & .03 & & & \\
\hline ly1l1kseverl11k guvenirlik & Erkek & 37 & 5.24 & .79 & .13 & 1.92 & 311 & .05 \\
\hline İyilikseyerlik seyoi & Kadın & 276 & 5.36 & .65 & .03 & 84 & 311 & 40 \\
\hline ly1l1kseverlik sevg1 & Erkek & 37 & 5.27 & .76 & .12 & .84 & 311 & .40 \\
\hline Alcakoönïllüll̈̈k & Kadın & 276 & 4.68 & .76 & .04 & & 311 & \\
\hline Aıçakgonumuiuk & Erkek & 37 & 4.54 & 1.01 & .16 & .99 & 311 & .32 \\
\hline Kisilerarasıuvum & Kadın & 276 & 4.74 & .88 & .05 & 33 & 311 & 73 \\
\hline Kışılerarası uyum & Erkek & 37 & 4.69 & .78 & .12 & .33 & 311 & .73 \\
\hline Kurallara uvma & Kadın & 276 & 4.25 & 1.07 & .06 & 224 & 311 & 02 \\
\hline Kurallara uyma & Erkek & 37 & 3.81 & 1.30 & .21 & 2.24 & 311 & .02 \\
\hline & Kadin & 276 & 4.53 & 1.05 & .06 & -112 & 311 & 26 \\
\hline Geleneksellik & Erkek & 37 & 4.74 & 1.32 & .21 & -1.12 & 311 & .26 \\
\hline Toplumsal güvenlik & Kadın & 276 & 5.38 & .66 & .04 & 1.91 & 311 & .05 \\
\hline
\end{tabular}




\begin{tabular}{|c|c|c|c|c|c|c|c|c|}
\hline & Erkek & 37 & 5.12 & 1.32 & .21 & & & \\
\hline \multirow{2}{*}{ Kişisel güvenlik } & Kadın & 276 & 5.00 & .75 & .04 & \multirow{2}{*}{3.03} & \multirow{2}{*}{311} & \multirow{2}{*}{.00} \\
\hline & Erkek & 37 & 4.59 & .93 & .15 & & & \\
\hline
\end{tabular}

$* \mathrm{p}<.05$ düzeyinde anlamlıdır.

Tablo 3'e göre okul öncesi öğretmen adaylarının değer alg1 alt boyutlarının cinsiyete göre anlamlı olarak farklılaşıp farklılaşmadığını belirlemek için yapılan t-testi sonucunda "kurallara uyma" ve "kişisel güvenlik" alt boyutları haricinde diğer alt boyutlarda farklılaşmanın olmadığı ortaya çıkmıştır. Kurallara uyma ve kişisel güvenlik alt boyutları ile cinsiyet arasında ortaya çıkan anlamlı farklılaşmanın kadın okul öncesi öğretmen adayları lehine olduğu belirlenmiş $(\mathrm{p}=2.24 ; \mathrm{p}<.05, \mathrm{p}=3.03, \mathrm{p}<.05)$. Saygınlık, başarı, hazcılık, öz yönelim davranış, evrenselcilik hoşgörü, evrenselcilik doğa, evrenselcilik ilgi, iyilikseverlik güvenirlik, iyilikseverlik sevgi, alçakgönüllülük, kişilerarası uyum ve toplumsal güvenlik alt boyutlarında kadın okul öncesi öğretmen adaylarının puanlarının ortalaması erkek okul öncesi öğretmen adaylarına göre daha yüksektir. Güç kaynakları, güç baskınlığı, uyarılma, öz yönelim düşünce ve geleneksellik boyutlarında ise erkek okul öncesi öğretmen adaylarının puan ortalamaları kadın okul öncesi öğretmen adaylarına göre daha yüksektir.

Araştırmanın üçüncü alt problemi olan “Okul öncesi öğretmen adaylarının değer algılarının eğitim-öğretim gördükleri sınıf düzeyine göre anlamlı şekilde farklılaşmakta mıdır?” sorusuna ilişkin olarak yapılan One Way ANOVA testi sonucunda elde edilen bulgular Tablo 4'de yer almaktadır.

Tablo 4: Okul öncesi öğretmen adaylarının değer algılarının eğitim-öğretim gördükleri sınıf düzeyine göre farklılaşıp farklılaşmadığını belirlemek amacıyla yapılan tek yönlü varyans analizi sonuçları

\section{$f, \overline{\mathrm{x}}$ ve $s s$ Değerleri}

ANOVA Sonuçları

\begin{tabular}{|c|c|c|c|c|c|c|c|c|c|c|c|}
\hline Puan & Grup & $N$ & $\overline{\mathrm{x}}$ & $S S$ & Var. K. & $K T$ & $S d$ & $K O$ & $F$ & $p$ & Fark \\
\hline \multirow{4}{*}{ Saygınlık } & 1.sinif & 90 & 5.14 & .87 & G.Aras1 & 5.99 & 3 & 1.99 & \multirow{4}{*}{2.97} & \multirow{4}{*}{.03} & \multirow{4}{*}{$1>4$} \\
\hline & $2 . \sin 1 f$ & 88 & 5.02 & .75 & G.İçi & 207.83 & 309 & .67 & & & \\
\hline & $3 . \sin 1 f$ & 102 & 5.00 & .79 & Toplam & 213.82 & 312 & & & & \\
\hline & 4.sinif & 33 & 4.64 & .88 & & & & & & & \\
\hline \multirow{4}{*}{ Güç kaynakları } & 1.sinif & 90 & 3.55 & 1.26 & G.Arası & 8.73 & 3 & 2.91 & \multirow{4}{*}{1.95} & \multirow{4}{*}{.12} & \\
\hline & $\overline{2 . \sin 1 f}$ & 88 & 3.47 & 1.22 & G.İçi & 459.35 & 309 & 1.48 & & & \\
\hline & 3.sinif & 102 & 3.43 & 1.20 & Toplam & 468.08 & 312 & & & & \\
\hline & 4.sinif & 33 & 4.01 & 1.09 & & & & & & & \\
\hline \multirow{4}{*}{ Güç baskınlığg 1} & 1.sinif & 90 & 3.62 & 1.23 & G.Arası & 2.41 & 3 & .80 & \multirow{4}{*}{.68} & \multirow{4}{*}{.56} & \\
\hline & 2.sinif & 88 & 3.60 & 1.03 & G.İçi & 362.43 & 309 & 1.17 & & & \\
\hline & $3 . \sin 1 f$ & 102 & 3.64 & 1.01 & Toplam & 364.85 & 312 & & & & \\
\hline & 4.sinif & 33 & 3.90 & .98 & & & & & & & \\
\hline \multirow{4}{*}{ Başarı } & 1.sinif & 90 & 4.92 & .83 & G.Aras1 & 3.23 & 3 & 1.08 & \multirow{4}{*}{1.97} & \multirow{4}{*}{.11} & \\
\hline & 2.sinif & 88 & 4.89 & .63 & G.İçi & 196.39 & 309 & .54 & & & \\
\hline & 3.sinif & 102 & 4.98 & .67 & Toplam & 172.63 & 312 & & & & \\
\hline & $4 . \sin 1 f$ & 33 & 4.62 & .90 & & & & & & & \\
\hline \multirow{4}{*}{ Hazcılık } & 1.sinif & 90 & 5.24 & .67 & G.Arası & 3.27 & 3 & 1.09 & \multirow{4}{*}{2.40} & \multirow{4}{*}{.06} & \\
\hline & 2.sinif & 88 & 5.28 & .59 & G.İçi & 140.39 & 309 & .45 & & & \\
\hline & 3.sinif & 102 & 5.19 & .69 & Toplam & 143.66 & 312 & & & & \\
\hline & $\overline{4 . \sin 1 \mathrm{f}}$ & 33 & 4.92 & .81 & & & & & & & \\
\hline \multirow{4}{*}{ Uyarılma } & 1.sinif & 90 & 4.78 & .99 & G.Aras1 & .64 & 3 & .21 & \multirow{4}{*}{.28} & \multirow{4}{*}{.83} & \\
\hline & 2.sinif & 88 & 4.76 & .83 & G.İçi & 233.73 & 309 & .75 & & & \\
\hline & 3.sinif & 102 & 4.79 & .78 & Toplam & 234.37 & 312 & & & & \\
\hline & 4.sinıf & 33 & 4.63 & .83 & & & & & & & \\
\hline \multirow{3}{*}{ Öz yönelim davranış } & 1.sinif & 90 & 5.37 & .71 & G.Aras1 & 5.70 & 3 & 1.90 & \multirow{3}{*}{3.96} & \multirow{3}{*}{.00} & \multirow{3}{*}{$\begin{array}{l}1>4, \\
3>4\end{array}$} \\
\hline & $2 . \sin 1 f$ & 88 & 5.32 & .68 & G.İçi & 148.29 & 309 & .48 & & & \\
\hline & $3 . \sin 1 f$ & 102 & 5.42 & .60 & Toplam & 153.99 & 312 & & & & \\
\hline
\end{tabular}




\begin{tabular}{|c|c|c|c|c|c|c|c|c|c|c|c|}
\hline & 4.sinif & 33 & 4.95 & .88 & & & & & & & \\
\hline \multirow{4}{*}{ Öz yönelim düşünce } & $1 . \sin 1 \mathrm{f}$ & 90 & 5.29 & .71 & G.Aras1 & 6.15 & 3 & 2.05 & \multirow{4}{*}{4.17} & \multirow{4}{*}{.00} & \multirow{4}{*}{$\begin{array}{l}1>4, \\
2>4, \\
3>4\end{array}$} \\
\hline & $2 . \sin 1 f$ & 88 & 5.27 & .62 & G.İçi & 151.85 & 309 & .49 & & & \\
\hline & 3.sinif & 102 & 5.23 & .66 & Toplam & 158.01 & 312 & & & & \\
\hline & 4.sinif & 33 & 4.81 & .91 & & & & & & & \\
\hline \multirow{4}{*}{ Evrenselcilik hoşgörü } & $1 . \sin 1 f$ & 90 & 5.12 & .80 & G.Aras1 & 1.30 & 3 & .43 & \multirow{4}{*}{.77} & \multirow{4}{*}{.51} & \\
\hline & $2 . \sin 1 f$ & 88 & 5.06 & .77 & G.İçi & 173.60 & 309 & .56 & & & \\
\hline & $3 . \sin 1 f$ & 102 & 5.15 & .68 & Toplam & 174.90 & 312 & & & & \\
\hline & $\overline{4 . \sin 1 f}$ & 33 & 4.93 & .72 & & & & & & & \\
\hline \multirow{4}{*}{ Evrenselcilik doğa } & $1 . \sin 1 f$ & 90 & 5.05 & .93 & G.Aras1 & 2.30 & 3 & .76 & \multirow{4}{*}{1.09} & \multirow{4}{*}{.35} & \\
\hline & 2.sinif & 88 & 5.00 & .78 & G.İçi & 216.47 & 309 & .70 & & & \\
\hline & 3.sinif & 102 & 4.97 & .72 & Toplam & 218.77 & 312 & & & & \\
\hline & 4.sinif & 33 & 4.74 & .98 & & & & & & & \\
\hline \multirow{4}{*}{ Evrenselcilik ilgi } & 1.sinif & 90 & 5.49 & .61 & G.Aras1 & 5.11 & 3 & 1.70 & \multirow{4}{*}{4.15} & \multirow{4}{*}{.00} & \multirow{4}{*}{$\begin{array}{l}1>4, \\
3>4\end{array}$} \\
\hline & 2.sinif & 88 & 5.40 & .66 & G.İçi & 127.00 & 309 & .41 & & & \\
\hline & 3.sinif & 102 & 5.42 & .55 & Toplam & 132.12 & 312 & & & & \\
\hline & $4 . \sin 1 f$ & 33 & 5.04 & .87 & & & & & & & \\
\hline \multirow{4}{*}{ İyilikseverlik güvenirlik } & 1.sinif & 90 & 5.53 & .66 & G.Aras1 & 5.24 & 3 & 1.75 & \multirow{4}{*}{4.07} & \multirow{4}{*}{.00} & \multirow{4}{*}{$\begin{array}{l}1>4 \\
3>4\end{array}$} \\
\hline & 2.sinif & 88 & 5.42 & .67 & G.İçi & 132.75 & 309 & .43 & & & \\
\hline & 3.sinif & 102 & 5.48 & .55 & Toplam & 138.00 & 312 & & & & \\
\hline & 4.sinif & 33 & 5.08 & .86 & & & & & & & \\
\hline \multirow{4}{*}{ İyilikseverlik sevgi } & 1.sinif & 90 & 5.46 & .62 & G.Aras1 & 7.72 & 3 & 2.57 & & & \\
\hline & 2.sinif & 88 & 5.32 & .63 & G.İçi & 133.53 & 309 & .43 & 5.95 & 00 & $\begin{array}{l}1>4, \\
2>4\end{array}$ \\
\hline & $3 . \sin 1 f$ & 102 & 5.42 & .59 & Toplam & 141.25 & 312 & & 5.95 & .00 & $3>4$ \\
\hline & 4.sinif & 33 & 4.92 & .93 & & & & & & & \\
\hline & 1.sinif & 90 & 4.82 & .78 & G.Aras1 & 4.50 & 3 & 1.50 & & & \\
\hline Alcakoönüllïlük & 2.sinif & 88 & 4.62 & .83 & G.İçi & 195.60 & 309 & .63 & 237 & 07 & \\
\hline Aıçakgomunuıuk & 3.sinif & 102 & 4.62 & .74 & Toplam & 200.10 & 312 & & 2.51 & .01 & \\
\hline & 4.sinif & 33 & 4.43 & .85 & & & & & & & \\
\hline & 1.sinif & 90 & 4.69 & 1.01 & G.Aras1 & .32 & 3 & .10 & & & \\
\hline$V$ icilaroresump & $2 . \sin 1 f$ & 88 & 4.76 & .74 & G.İçi & 235.14 & 309 & .76 & 14 & 02 & \\
\hline kişıerarası uyum & 3.sinif & 102 & 4.76 & .81 & Toplam & 235.47 & 312 & & .14 & .95 & \\
\hline & $4 . \sin 1 f$ & 33 & 4.70 & .94 & & & & & & & \\
\hline & 1.sinif & 90 & 3.99 & 1.32 & G.Aras1 & 9.55 & 3 & 3.18 & & & \\
\hline Kurallara uyma & 2.sinif & 88 & 4.11 & .99 & G.İçi & 373.87 & 309 & 1.21 & 263 & 05 & \\
\hline nuranara uyma & 3.sinif & 102 & 4.41 & .97 & Toplam & 383.43 & 312 & & 2.03 & .00 & \\
\hline & $4 . \sin 1 f$ & 33 & 4.32 & 1.04 & & & & & & & \\
\hline & 1.sinif & 90 & 4.71 & 1.15 & G.Aras1 & 4.01 & 3 & 1.33 & & & \\
\hline Gelonelcollit & 2.sinif & 88 & 4.48 & 1.04 & G.İçi & 367.85 & 309 & 1.19 & 1123 & 34 & \\
\hline Gelenekseп1к & $3 . \sin 1 f$ & 102 & 4.55 & 1.09 & Toplam & 371.86 & 312 & & 1.123 & .54 & \\
\hline & 4.sinif & 33 & 4.35 & 1.00 & & & & & & & \\
\hline & 1.sinif & 90 & 5.42 & .73 & G.Aras1 & 5.58 & 3 & 1.86 & & & \\
\hline Tonlumsal oüvenlik & 2.sinif & 88 & 5.38 & .63 & G.İçi & 128.05 & 309 & .58 & 315 & 02 & $1>4$ \\
\hline 10piumsal guventIK & 3.sinif & 102 & 5.38 & .83 & Toplam & 187.63 & 312 & & 5.13 & .02 & $1>4$ \\
\hline & $4 . \sin 1 f$ & 33 & 4.96 & .95 & & & & & & & \\
\hline & 1.sinif & 90 & 4.95 & .86 & G.Arası & 2.68 & 3 & .89 & & & \\
\hline Kicicel qüуenlik & 2.sinif & 88 & 5.03 & .70 & G.İçi & 190.00 & 309 & .61 & 145 & 22 & \\
\hline Kişisel guvenı1K & 3.sinif & 102 & 4.97 & .72 & Toplam & 192.68 & 312 & & 1.43 & .22 & \\
\hline & 4.sinif & 33 & 4.70 & .90 & & & & & & & \\
\hline
\end{tabular}

*p<.05 düzeyinde anlamlıdır.

Tablo 4'e göre okul öncesi öğretmen adaylarının değer alg1 alt boyutlarının eğitim-öğretim görülen sınıf düzeyine göre anlamlı olarak farklılaşıp farklılaşmadığını belirlemek için yapılan tek yönlü varyans analizi (ANOVA) sonucunda "saygınlık”, “öz yönelim davranış”, “öz yönelim düşünce”, "evrenselcilik ilgi”, "iyilikseverlik güvenirlik”, “iyilikseverlik sevgi” ve "toplumsal güvenlik" alt boyutları haricinde diğer alt boyutların farklılaşmanın olmadığı 
ortaya çıkmıştır. "Saygınlık" ve "toplumsal güvenlik" alt boyutlarında ortaya çıkan anlamlı farklılaşmanın birinci sınıf ile dördüncü sınıfta öğrenim gören okul öncesi öğretmenleri arasında birinci sınıfta öğrenim görenler lehine olduğu ortaya çıkmıştır. "Öz yönelim davranış", "iyilikseverlik güvenirlik" ve "evrenselcilik ilgi" alt boyutlarında ortaya çıkan anlamlı farklılaşmanın birinci sınıf ile dördüncü sınıf ve üçüncü sınıf ile dördüncü sınıf arasında birinci ve üçüncü sınıfta öğrenim gören okul öncesi öğretmen adayları lehine olduğu belirlenmiştir. "Öz yönelim düşünce" ve "iyilikseverlik sevgi" alt boyutlarında ortaya çıkan anlamlı farklılaşmanın birinci sınıf ile dördüncü sınıf, ikinci sınıf ile dördüncü sınıf ve üçüncü sınıf ile dördüncü sınıf arasında birinci, ikinci ve üçüncü sınıfta öğrenim gören okul öncesi öğretmen adayları lehine olduğu ortaya çıkmıştır.

Araştırmanın dördüncü alt problemi olan "Okul öncesi öğretmen adaylarının değer algılarının akademik başarı düzeyine göre anlamlı şekilde farklılaşmakta mıdır?” sorusuna ilişkin olarak yapılan One Way ANOVA testi sonucunda elde edilen bulgular Tablo 5'de yer almaktadır.

Tablo 5: Okul öncesi öğretmen adaylarının değer algılarının akademik başarı düzeyine göre farklılaşıp farklılaşmadığını belirlemek amacıyla yapılan tek yönlü varyans analizi sonuçları

\section{$f, \overline{\mathrm{x}}$ ve $s s$ Değerleri}

ANOVA Sonuçları

\begin{tabular}{|c|c|c|c|c|c|c|c|c|c|c|c|}
\hline Puan & Grup & $N$ & $\overline{\mathrm{x}}$ & $s S$ & Var. K. & $K T$ & $S d$ & $K O$ & $F$ & $p$ & Fark \\
\hline \multirow{3}{*}{ Saygınlık } & Düşük & 114 & 5.01 & .94 & G.Aras1 & .49 & 2 & .24 & \multirow{3}{*}{.36} & \multirow{3}{*}{.69} & \\
\hline & Orta & 121 & 5.05 & .78 & G.İçi & 213.33 & 310 & .68 & & & \\
\hline & Yüksek & 78 & 4.95 & .71 & Toplam & 213.82 & 312 & & & & \\
\hline \multirow{3}{*}{ Güç kaynakları } & Düşük & 114 & 3.57 & 1.30 & G.Aras1 & 1.07 & 2 & .53 & \multirow{3}{*}{.35} & \multirow{3}{*}{.70} & \\
\hline & Orta & 121 & 3.47 & 1.19 & G.İçi & 467.01 & 310 & 1.50 & & & \\
\hline & Yüksek & 78 & 3.61 & 1.14 & Toplam & 468.08 & 312 & & & & \\
\hline \multirow{3}{*}{ Güç baskınlığı } & Düşük & 114 & 3.72 & 1.12 & G.Aras1 & 2.41 & 2 & 1.20 & \multirow{3}{*}{1.03} & \multirow{3}{*}{.35} & \\
\hline & Orta & 121 & 3.54 & 1.07 & G.İçi & 362.44 & 310 & 1.16 & & & \\
\hline & Yüksek & 78 & 3.72 & 1.01 & Toplam & 364.85 & 312 & & & & \\
\hline \multirow{3}{*}{ Başarı } & Düşük & 114 & 4.78 & .84 & G.Aras1 & 5.27 & 2 & 2.63 & \multirow{3}{*}{4.88} & \multirow{3}{*}{.00} & \multirow{3}{*}{$3>1$} \\
\hline & Orta & 121 & 4.87 & .71 & G.İçi & 167.35 & 310 & .54 & & & \\
\hline & Yüksek & 78 & 5.11 & .56 & Toplam & 172.63 & 312 & & & & \\
\hline \multirow{3}{*}{ Hazcılik } & Düşük & 114 & 5.26 & .72 & G.Aras1 & .59 & 2 & .29 & \multirow{3}{*}{.64} & \multirow{3}{*}{.52} & \\
\hline & Orta & 121 & 5.15 & .69 & G.İçi & 143.07 & 310 & .46 & & & \\
\hline & Yüksek & 78 & 5.21 & .58 & Toplam & 143.66 & 312 & & & & \\
\hline \multirow{3}{*}{ Uyarılma } & Düşük & 114 & 4.81 & .99 & G.Aras1 & 1.65 & 2 & .82 & \multirow{3}{*}{1.10} & \multirow{3}{*}{.33} & \\
\hline & $\overline{\text { Orta }}$ & 121 & 4.67 & .78 & G.İçi & 232.72 & 310 & .75 & & & \\
\hline & Yüksek & 78 & 4.83 & .77 & Toplam & 234.37 & 312 & & & & \\
\hline \multirow{3}{*}{ Öz yönelim davranış } & Düşük & 114 & 5.32 & .76 & G.Aras1 & 2.32 & 2 & 1.16 & \multirow{3}{*}{2.37} & \multirow{3}{*}{.09} & \\
\hline & Orta & 121 & 5.25 & .72 & G.İçi & 151.67 & 310 & .48 & & & \\
\hline & Yüksek & 78 & 5.47 & .54 & Toplam & 153.99 & 312 & & & & \\
\hline \multirow{3}{*}{ Öz yönelim düşünce } & Düşük & 114 & 5.24 & .74 & G.Aras1 & 1.12 & 2 & .56 & \multirow{3}{*}{1.11} & \multirow{3}{*}{.33} & \\
\hline & Orta & 121 & 5.14 & .74 & G.İçi & 156.88 & 310 & .50 & & & \\
\hline & Yüksek & 78 & 5.29 & .60 & Toplam & 158.01 & 312 & & & & \\
\hline \multirow{3}{*}{ Evrenselcilik hoşgörü } & Düşük & 114 & 5.09 & .87 & G.Aras1 & 5.45 & 2 & 2.72 & & & \\
\hline & Orta & 121 & 4.96 & .69 & G.İçi & 169.44 & 310 & .54 & 4.99 & .00 & $3>2$ \\
\hline & Yüksek & 78 & 5.30 & .55 & Toplam & 174.90 & 312 & & & & \\
\hline & Düşük & 114 & 4.99 & .93 & G.Aras1 & 2.11 & 2 & 1.05 & & & \\
\hline Evrenselcilik doğa & Orta & 121 & 4.89 & .86 & G.İçi & 216.66 & 310 & .69 & 1.51 & .22 & \\
\hline & Yüksek & 78 & 5.10 & .59 & Toplam & 218.77 & 312 & & & & \\
\hline & Düşük & 114 & 5.44 & .72 & G.Aras1 & 1.41 & 2 & .70 & & & \\
\hline Evrenselcilik ilgi & Orta & 121 & 5.31 & .61 & G.İçi & 130.71 & 310 & .42 & 1.67 & .18 & \\
\hline & Yüksek & 78 & 5.46 & .56 & Toplam & 132.12 & 312 & & & & \\
\hline İyilikseverlik güvenirlik & Düşük & 114 & 5.48 & .72 & G.Aras1 & 1.06 & 2 & .53 & 1.20 & .30 & \\
\hline
\end{tabular}




\begin{tabular}{|c|c|c|c|c|c|c|c|c|c|c|c|}
\hline & Orta & 121 & 5.36 & .68 & G.İçi & 136.93 & 310 & .44 & & & \\
\hline & Yüksek & 78 & 5.49 & .52 & Toplam & 138.00 & 312 & & & & \\
\hline \multirow{3}{*}{ İyilikseverlik sevgi } & Düşük & 114 & 5.46 & .69 & G.Aras1 & 3.05 & 2 & 1.52 & \multirow{3}{*}{3.42} & \multirow{3}{*}{.03} & \multirow{3}{*}{$1>2$} \\
\hline & Orta & 121 & 5.23 & .71 & G.İçi & 138.20 & 310 & .44 & & & \\
\hline & Yüksek & 78 & 5.38 & .55 & Toplam & 141.25 & 312 & & & & \\
\hline \multirow{3}{*}{ Alçakgönüllülük } & Düşük & 114 & 4.71 & .79 & G.Aras1 & .68 & 2 & .34 & \multirow{3}{*}{.53} & \multirow{3}{*}{.58} & \\
\hline & Orta & 121 & 4.60 & .85 & G.İçi & 199.42 & 310 & .64 & & & \\
\hline & Yüksek & 78 & 4.67 & .71 & Toplam & 200.10 & 312 & & & & \\
\hline \multirow{3}{*}{ Kişilerarası uyum } & Düşük & 114 & 4.77 & .94 & G.Aras1 & 4.53 & 2 & 2.26 & \multirow{3}{*}{3.04} & \multirow{3}{*}{.04} & \multirow{3}{*}{$3>2$} \\
\hline & Orta & 121 & 4.60 & .84 & G.İçi & 230.93 & 310 & .74 & & & \\
\hline & Yüksek & 78 & 4.90 & .75 & Toplam & 235.47 & 312 & & & & \\
\hline \multirow{3}{*}{ Kurallara uyma } & Düşük & 114 & 3.98 & 1.27 & G.Aras1 & 20.15 & 2 & 10.07 & \multirow{3}{*}{8.59} & \multirow{3}{*}{.00} & \multirow{3}{*}{$\begin{array}{l}3>1, \\
3>2\end{array}$} \\
\hline & Orta & 121 & 4.12 & 1.00 & G.İçi & 363.27 & 310 & 1.17 & & & \\
\hline & Yüksek & 78 & 4.62 & .86 & Toplam & 383.43 & 312 & & & & \\
\hline \multirow{3}{*}{ Geleneksellik } & Düşük & 114 & 4.53 & 1.25 & G.Aras1 & 2.39 & 2 & 1.19 & \multirow{3}{*}{1.00} & \multirow{3}{*}{.36} & \\
\hline & Orta & 121 & 4.48 & 1.00 & G.İçi & 369.46 & 310 & 1.19 & & & \\
\hline & Yüksek & 78 & 4.70 & .94 & Toplam & 371.86 & 312 & & & & \\
\hline \multirow{3}{*}{ Toplumsal güvenlik } & Düşük & 114 & 5.25 & .97 & G.Aras1 & 2.30 & 2 & 1.15 & \multirow{3}{*}{1.92} & \multirow{3}{*}{.14} & \\
\hline & Orta & 121 & 5.37 & .67 & G.İçi & 185.33 & 310 & .59 & & & \\
\hline & Yüksek & 78 & 5.47 & .54 & Toplam & 187.63 & 312 & & & & \\
\hline \multirow{3}{*}{ Kişisel güvenlik } & Düşük & 114 & 4.88 & .91 & G.Aras1 & 2.65 & 2 & 1.32 & \multirow{3}{*}{2.16} & \multirow{3}{*}{.11} & \\
\hline & Orta & 121 & 4.92 & .71 & G.İçi & 190.03 & 310 & .61 & & & \\
\hline & Yüksek & 78 & 5.11 & .67 & Toplam & 192.68 & 312 & & & & \\
\hline
\end{tabular}

$* \mathrm{p}<.05$ düzeyinde anlamlıdır.

1: Düşük, 2: Orta, 3: Yüksek

Tablo 5'e göre okul öncesi öğretmen adaylarının değer algı alt boyutlarının akademik başarı düzeyine göre anlamlı olarak farklılaşıp farklılaşmadığını belirlemek için yapılan tek yönlü varyans analizi (ANOVA) sonucunda "başarı", "evrenselcilik hoşgörü", "iyilikseverlik sevgi", "kişilerarası uyum" ve "kurallara uyma" alt boyutları haricinde diğer alt boyutların farklılaşmanın olmadığı belirlenmiştir. "Başarı" alt boyutunda ortaya çıan anlamlı farklılaşmanın yüksek akademik başarı düzeyine sahip olanlar ile düşük akademik başarı düzeyinde olan okul öncesi öğretmen adayları arasında yüksek düzeyde akademik başarısı olanlar lehine olduğu ortaya çıkmıştır. "Evrenselcilik hoşgörü" ve "kişilerarası uyum" alt boyutlarında ortaya çıkan anlamlı farklılaşmanın yüksek akademik başarı düzeyine sahip olanlar ile orta akademik başarı düzeyinde olan okul öncesi öğretmen adayları arasında yüksek düzeyde akademik başarısı sahip olanlar lehine olduğu belirlenmiştir. "İyilikseverlik sevgi” alt boyutunda ortaya çıkan anlamlı farklılaşmanın düşük akademik başarı düzeyine sahip olanlar ile orta akademik başarı düzeyinde olan okul öncesi öğretmen adayları arasında düşük düzeyde akademik başarı gösterenler lehine olduğu belirlenmiştir. "Kurallara uyma" alt boyutunda ortaya çıkan anlamlı farklılaşmanın yüksek akademik başarı düzeyine sahip olanlar ile düşük ve orta akademik başarı düzeyinde bulunan okul öncesi öğretmen adayları arasında ortaya çıkmış olup yüksek düzeyde akademik başarı gösterenler lehinedir.

\section{Sonuç, Tartışma ve Öneriler}

Okul öncesi öğretmen adaylarının değer algıları incelendiğinde en yüksek değer algı becerisinin iyilikseverlik güvenirlik, en düşük değer algı becerisinin de güç kaynakları olduğu sonucuna ulaşılmıştır. Elde edilen bu sonuç, Dilmaç, Bozgeyikli ve Çıkılı'nın (2008) öğretmen adayları ile gerçekleştirdiği çalışmanın sonuçları ile evrensellik, güvenlik, özyönelim ve iyilikseverlik boyutlarının en çok benimsenen değer algıları olması, güç boyutunun ise en az benimsenen değerler arasında yer alması sonuçları ile örtüşmektedir. Fırat ve Açıkgöz'ün (2012) ilköğretim okullarındaki öğretmenlerin değer algılarını incelediği araştırmasında da evrensellik, iyilikseverlik, güvenlik ve özyönelim boyutlarının en çok tercih edilen boyutlar olması bakımından benzer sonuçlar ortaya koyulmuştur. . Bunun yanında Çileli ve Tezer (1998), Aydın (2003), Keskin ve Sağlam (2014), Yalız-Solmaz (2015) tarafından yapılan çalışmalarda özgürlük ve toplumsal değerlere ilişkin algıların yüksek olduğu belirlenmiştir. Okul öncesi öğretmen adaylarının değer algıları oluşurken bireylerin portrelerinde iyilikseverlik güvenirliğin olması gerektiği önemli görülmektedir. Değer algısının oluşacağı bir portrenin içerisinde mutlaka iyilikseverlik ve güvenirliğin olması 
gerektiği düşünülebilir. Böylece bireyler iyilik ve güvenin olduğu yerde kendilerini daha rahat ifade edecekler değerlerin oluşması daha kolay olacaktır. Okul öncesi öğretmen adaylarının değer algı becerileri incelendiğinde en az olması gereken beceriyi güç kaynakları olarak belirtmelerinde birey üzerinde güç kullanımın bireyde değer oluşmasında ve değerin bireyde vücut bulmasında olumsuz etkisi olacağını düşünmeleridir. Bu sebeplerden dolayı güç kaynaklarının değer portresinin oluşmasında olumsuz bir etkisinin olacağı söylenebilir.

Okul öncesi öğretmen adaylarının değer algı alt boyutları olan kurallara uyma ve kişisel güvenlik alt boyutları hariç cinsiyete göre anlamlı şekilde farklılaşmadığ 1 sonucuna ulaşılmıştır. Ortaya çıkan bu sonuç Güven (2017), Mehmedoğlu (2006) tarafindan yapılan çalışmalardan elde edilen sonuçlar ile benzerlik göstermektedir. Literatürde değer yargılarının cinsiyete göre farklılaştığı sonuçlar da ortaya konulmuştur. Bu bağlamda Dilmaç, Bozgeyikli ve Çıkılı'nın (2008) öğretmen adayları ile gerçekleştirdiği araştırmada evrensellik ve "özyönelim” boyutlarında erkek öğretmen adaylarının lehine; güç boyutunda ise kadın öğretmen adaylarının lehine anlamlı bir fark söz konusudur. Keskin ve Sağlam'ın (2014) araştırmasında da öğretmen adaylarının insani değerlere sahip olma düzeylerinde, “entellektüel değerler”, maneviyat ve özgürlük boyutlarında kadın öğretmen adaylarının lehine anlamlı şekilde farklılaştığı görülmektedir. Ayrıca Fırat ve Açıkgöz’ün (2012) araştırmasında, kadınların başarı, hazcılık, evrensellik, geleneksellik ve güvenlik boyutlarına erkeklerden daha çok önem verdiği görülmektedir.

Kurallara uyma ve kişisel güvenlik alt boyutları olan becerilerin kadın okul öncesi öğretmenlerinin daha yüksek olduğu elde edilen bir başka sonuçtur. Kadın okul öncesi öğretmen adayları değer portrelerinin oluşmasında erkek öğretmen adaylarına göre daha fazla kurallara uymaya özen göstermektedirler. Bu durumun ortaya çıkmasında kadın okul öncesi öğretmen adaylarının daha düzenli olmaları, belirlenen şartlara uygun hareket etmeye daha uyumlu oldukları etkendir. Kişisel güvenlik alt boyutunda kadın okul öncesi öğretmen adaylarının puanlarının daha yüksek çıkması değerlerin portrelerde oluşmasında güvenli bir ortamı tercih etmelerinden kaynaklanmaktadır. Böylece kişisel güvenliğin korunması değerlerin oluşmasında bireylerin portrelerine oturmasında daha etken olduğu söylenebilir.

Araştırma sonucunda okul öncesi öğretmen adaylarının değer alg1 alt becerilerinden olan saygınlık, öz yönelim davranış, öz yönelim düşünce, evrenselcilik ilgi, iyilikseverlik güvenirlik, iyilikseverlik sevgi ve toplumsal güvenliğin sınıf düzeyine göre alt sınıf düzeyindeki öğretmen adaylarının lehine anlamlı olarak farklılaştı̆̆ ortaya çıkmıştır. Keskin ve Sağlam'ın (2014) araştırmasında ise ortaya çıkan anlamlı farkın 2. ve 3. sınıf öğrencilerin lehine olduğu görülmektedir. Sonuçlar bu anlamda Coşkun ve Yıldırım (2009), Yalız-Solmaz (2015) ve Güven (2017) tarafından yapılan çalışmalarla benzerlik göstermemekte olup bu çalışmalarda sınıf düzeyine göre anlamlı bir farklılaşma ortaya çıkmamıştır. Değer algısının oluşmasında saygınlık ve toplumsal güvenlik boyutunda birinci sınıf öğrencilerinin dördüncü sınıf öğrencilerine göre puanlarının anlamlı düzeyde yüksek olduğu ortaya çıkmıştır. Birinci sınıfta öğrenim gören okul öncesi öğretmen adaylarının değer oluşmasında saygınlığın daha fazla olması gerektiğini belirtmelerinde üniversite eğitim sürecine gelirken saygın olmaya karşı inançları etkendir. Ayrıca birinci sınıfta öğrenim gören okul öncesi öğretmen adaylarının toplumsal güvenlik sağlanarak değerler algısının oluşmasında beklentilerinin daha yüksek çıkmasında toplumun güven içerisinde olmasının değerin oluşmasında etken bir faktör olacağına olan inançlarının yadsınamayacak olmasıdır. Öz yönelimli davranış, iyilikseverlik güvenirlik ve evrenselcilik ilgi alt boyutlarında ise dördüncü sınıfta yer alan okul öncesi öğretmen adaylarının puanlarının daha düşük çıktığı belirlenmiştir. Bu durumun ortaya çıkmasında öğrencilerin üst sınıf seviyelerine geldikçe öz yönelim, iyilikseverlik ve evrenselciliğin değer algısı oluşmasında önemini kaybettiğine ilişkin inançlarının artmış olmasının etken olduğu söylenebilir. Öz yönelimli düşünce ve iyilikseverlik sevgi alt boyutlarında ise dördüncü sınıfta bulunan okul öncesi öğretmen adaylarının puanlarının daha düşük olduğu, bu alt boyutlarda birinci, ikinci ve üçüncü sınıfta öğrenim gören okul öncesi öğretmen adaylarının puanlarının daha yüksek olduğu sonucuna ulaşılmıştır. Ortaya çıkan bu sonuç doğrultusunda öze dönük düşünme sonucu oluşan değer algılarında azalmanın meydana gelmesinde alınan eğitim sonucunda bireysellikten uzaklaşmanın olduğu söylenebilir.

Okul öncesi öğretmen adaylarının değer algı alt becerilerinden olan başarı, evrenselcilik hoşgörü, iyilikseverlik sevgi, kişilerarası uyum ve kurallara uymanın akademik başarı düzeyine göre anlamlı bir şekilde farklılaştığı ortaya çıkmıştır. Değer algısı alt becerilerinden olan başarının yüksek düzeyde başarı gösteren okul öncesi öğretmenler lehine olduğu görülmektedir. Akademik başarının yüksek olması alt becerilerden olan başarının da yüksek düzeyde olmasından dolayı akademik başarı değer alt becerisinin akademik başarı ile paralellik taşıdığı 
söylenebilir. Değer alg1 alt becerilerinden olan evrenselcilik hoşgörü ve kişilerarası uyum puanlarının akademik başarısı yüksek olanlarda orta düzeyde olanlara göre daha yüksektir. Bu sebepten dolayı akademik başarının evrenselcilik ve kişilerarası uyumu geliştirmede etkili olduğunu söyleyebiliriz. İyilikseverlik sevgi alt boyutunda akademik başarı düzeyine göre düşük düzeyde olan okul öncesi öğretmen adaylarının puanları daha yüksek çıkmıştır. Elde edilen bu sonuç akademik başarısı düşük olan okul öncesi öğretmenlerinin iyilikseverlik sevginin gelişmesinde daha etkili olduğu söylenebilir. Kurallara uyma alt boyutunda ise anlamlı farklılaşmanın yüksek düzey ile orta ve düşük düzeyde olanlar arasında yüksek düzeydekiler lehine olduğu elde edilen bir başka sonuçtur. Bu sonuç akademik başarının yüksek olması değer algı becerilerinden olan kurallara uyma boyutunu olumlu yönde etkileyen bir unsur olduğunu söylememize olanak sağlamaktadır.

Araştırmada ortaya çıkan sonuçlar doğrultusunda okul öncesi öğretmen adaylarının değer algı becerilerinden olan güç kaynakları içerisinde yer alan olumlu güç kaynakları desteklenmelidir. Erkek öğretmen adaylarına kurallara uygun bir yaşam sürmeye ve kişisel güvenliklerini sağlamaya yönelik çalışmalar yapılmalıdır. Farklı sınıf düzeyinde eğitim gören okul öncesi öğretmen adaylarının birbirleri ile kaynaşmaları sağlanmalıdır. Değer algı becerilerini geliştirmek için okul öncesi öğretmen adaylarının akademik başarılarının arttırılmasına yönelik çalışmalar yapilmalıdır. 


\section{Extended Abstract \\ Introduction}

Values are motifs forming the structure of society. All of these motifs reflect society. Value judgments are different and unique between societies. Values have always been present in our thoughts and perceptions since the dawn of humanity. Humanity is freed by our adopted values. Though there are different classifications in the literature, there is one comprehensive classification related to values. According to this classification, values are dealt with in two dimensions as "horizontal" and "vertical". The horizontal dimension is investigated between two groups of "openness to innovation" and "conservative approach". On the openness to innovation side the values of "self-direction" and "stimulation" are located, while the conservative approach includes the values of "security", "conformity" and "tradition". The vertical dimension ranges from "self-enhancement" to "self-transcendency". The self-enhancement side includes "power" and "achievement", while the self-transcendency side includes "universalism" and "benevolence" values. The "hedonism" value type is shared between the openness to innovation and self-enhancement areas. Teachers have great responsibilities in the existence of values in society and in transferring them to future generations. New generations should be raised with our value judgements and the efforts displayed by teachers in adopting these value judgements is very valuable. As a result, it is important to know the value judgements of preservice teachers, the teachers of the future. Gaining value judgements from the first stage of teaching in preschool education is important in terms of forming the basis for later periods. As a result, the aim of this research is to investigate the value judgements of preschool teacher candidates. In line with this aim, the answers to the following questions were sought.

For preservice preschool teachers,

1) What are their value perceptions?

2) Do value perceptions significantly differ according to gender?

3) Do value perceptions significantly differ according to year level of education?

4) Do value perceptions significantly differ according to academic success levels?

\section{Method}

The research used the descriptive screening model with the aim of determining the value perceptions of preservice preschool teachers. The study group for the research comprised 313 preservice teachers attending a Department of Primary Education, Preschool Education branch in Turkey's northwest in the 2016-2017 educational year. Of the preservice teachers participating in the research, $88.2 \%$ were female and $11.8 \%$ were male. According to their class level, preservice teachers were mostly in the " $3{ }^{\text {rd }}$ year", with a rate of $32.6 \%$, with the highest rate of academic success at "moderate", with a rate of $38.7 \%$.

With the aim of investigating the value perceptions of preservice preschool teachers in terms of a variety of variables, the Personal Information Form developed by the researchers and the Portrait Values Questionnaire (PVQ57) were used. The Portrait Values Questionnaire (PVQ57) comprises 57 items, with 19 different value types, each including three items. The survey finds the value types of Face, Power-Resources, Power-Dominance, Achievement, Hedonism, Stimulation, Self-Direction-Action, Self-Direction-Thought, Universalism-Tolerance, Universalism-Nature, Universalism-Concern, Benevolence-Dependability, Benevolence-Caring, Humility, Conformity—Interpersonal, Conformity—Rules, Tradition, Security—Societal, and Security—Personal Safety. Each item included on this scale comprises word portraits which aid in expressing the importance of a certain behavior to the individual. For each question on the scale, participants are requested to mark the most appropriate choice from six intervals ( 1 - not like me at all, 2 - not like me, 3 - a little like me, 4 - somewhat like me, 5 - like me, 6 - very much like me).

The IBM SPSS 24 program was used to analyze data in the research. Descriptive statistics were used for data analysis, with analyses performed with the aim of determining whether the distribution of the data was parametric or not. As the skewness value for the nineteen subdimensions included in the PVQ57 scale tool were between -1.37 to .10 and the kurtosis values were between -.63 and 1.07, they showed normal distribution. As the distribution was parametric, all tests to be used in line with the aims of the research were chosen according to this. Difference tests 
used the $t$ test for two-way groups, and one-way analysis of variance for three or more groups. To determine differences according to gender, the $t$ test was used, while one-way analysis of variance was used to determine differences according to class level and academic success. With the aim of revealing which group caused the differences found as a result of one-way analysis of variance, the post hoc analysis of Scheffe test was used. The significance level of .05 was accepted for difference tests between groups.

\section{Results}

When the results of the research are examined, it was revealed that preservice preschool teachers had no differences for value subdimensions, apart from the "conformity—rules" and "security—personal safety" subdimensions. There was significant difference in the conformity-rules and security-personal safety subdimensions according to gender, in favor of female preservice preschool teachers $(\mathrm{p}=2.24 ; \mathrm{p}<.05, \mathrm{p}=3.03, \mathrm{p}<.05)$. The mean points for the subdimensions of face, achievement, hedonism, self-direction-action, universalism-tolerance, universalism-nature, universalism — concern, benevolence — dependability, benevolence — caring, humility, conformity—interpersonal, and security-societal were higher for female preservice preschool teachers compared to male preservice preschool teachers. For the dimensions of power-resources, power-dominance, stimulation, self-direction-thought and tradition, the mean points of male preservice preschool teachers were higher compared to female preservice preschool teachers.

According to the class level of preservice preschool teachers, apart from the value perception subdimensions of "face", "self-direction-action", "self-direction-thought", "universalism-concern", "benevolencedependability", "benevolence-caring" and "security_societal", there were no differences in the other subdimensions. The differences between the "face" and "security-society" subdimensions were between preschool teachers in the first year and fourth year, in favor of first year students. The significant differences in the "selfdirection-action", "benevolence-dependability", and "universalism—concern" subdimensions were between first year and fourth year students and between third year and fourth year students in favor of preservice preschool teachers attending first and third year teaching. The significant differences in "self-direction-thought" and "benevolencecaring" subdimensions were between first year and fourth year students, between second year and fourth year students, and between third year and fourth year students, in favor of preservice preschool teachers attending the first, second and third year of education.

According to academic success level, apart from the subdimensions of "achievement", "universalismtolerance", "benevolence — caring", "conformity—interpersonal", and "conformity—rules", all other subdimensions of value perceptions were not found to differ among preservice teachers. The "achievement" subdimension was found to be significantly different for preservice preschool teachers with high academic success and those with low academic success, in favor of preservice teachers with high academic success. The subdimensions of "universalism-tolerance" and "conformity - interpersonal" significantly differed between those with high academic success and those with moderate academic success, in favor of preservice preschool teachers with high academic success. The significant difference in the "benevolence-caring" subdimension was between those with low academic success and those with moderate academic success, in favor of preservice preschool teachers with low levels of academic success. The significant difference in the "conformity—rules" subdimension was between those with high academic success and those with low and moderate academic success in favor of preservice preschool teacher candidates with high levels of academic success.

\section{Discussion and Conclusion}

When the value perceptions of preservice preschool teachers are investigated, the highest value perception skill was for benevolence - dependability, with lowest value perception skill for power-resources. The results obtained show similarities to some studies, though some studies observed perceptions related to freedom and social values were highest. Apart from the subdimensions of conformity—rules and security—personal safety, it was concluded that none of the other value perception subdimensions of preservice teachers varied significantly according to gender.

According to another result of the research, the value perception subdimension skills of face, self-directionaction, self-direction - thought, universalism — concern, benevolence-dependability, benevolence — caring and security-societal varied significantly according to class level. This result of the research does not comply with other 
study results. Among the results, the face and security-societal dimensions within value perceptions were found to be significantly high for first year students compared to fourth year students. Preservice preschool teachers attending first year education state that face is required more for value formation, while as university education continues it affects their beliefs about face. The points for the subdimensions of self-direction-action, benevolence-dependability and universalism - concern were found to be lower for preservice preschool teachers attending fourth year education. The occurrence of this situation shows that there is an increase in beliefs about self-direction, benevolence and universalism losing their importance as upper class levels are reached.

It was revealed that the value perception subdimensions of achievement, universalism-tolerance, benevolence - caring, conformity - interpersonal, and conformity—rules significantly differed according to the academic success levels of preservice preschool teachers. The value perception subdimension of achievement was observed to be at high levels, in favor of preschool teachers with high levels of success. In line with the results of this research, the value perception skill of power-resources should be supported among preservice preschool teachers by including positive power resources. 


\section{Kaynaklar / References}

Akbaba-Altun, S. (2003). Eğitim yönetimi ve değerler. Değerler Ĕ̆itimi Dergisi, 1(1), 7-18.

Aydın, M. (2003). Gençliğin değer algısı: Konya örneği. Değerler Eğitimi Dergisi, 1(3), 121-144.

Balc1, F. A., \& Yanpar-Yelken, T. (2010). İlköğretim öğretmenlerinin “değer” kavramına yükledikleri anlamlar. Hacettepe Üniversitesi Ĕ̌itim Fakültesi Dergisi, 39, 81-90.

Coşkun, Y., \& Yıldırım, A. (2009). Üniversite öğrencilerinin değer düzeylerinin bazı değişkenler açısından incelenmesi. Yüzüncü Yıl Üniversitesi Eğitim Fakültesi Dergisi, 1(6), 311-328.

Çileli, M., \& Tezer, E. (1998). Life and value orientations of Turkish university students. Adolescence, 33(129), 219-224.

Demircioğlu, İ. H., \& Tokdemir, M. A. (2008). Değerlerin oluşturulma sürecinde tarih eğitimi: amaç, işlev ve içerik. Değerler Eğitimi Dergisi, 6(15), 69-88.

Dilmaç, B., Bozgeyikli, H., \& Çıkılı, Y. (2008). Öğretmen adaylarının değer algılarının farklı değişkenler açısından incelenmesi. Değerler Ĕ̈itimi Dergisi, 6(16), 69-91.

Güven, A. Z. (2017). Türkçe öğretmeni adaylarının değer algılarının farklı değişkenler açısından incelenmesi. International Journal of Language Academy, 5(1), 349-359.

Halstead, J. M., \& Taylor, M. J. (2000). Learning and teaching about values: a review of recent research. Cambridge Journal of Education, 30, 169-202.

Hoşgörür, V. (2017). Eğitimin toplumsal temelleri. Ö. Demirel \& Z. Kaya, (Ed.) Ĕgitim bilimine giriş (ss. 129-160). Ankara: Pegem Akademi.

Inglehart, R., \& Baker, W. E. (2000). Modernization, cultural change, and the persistence of traditional values. American Sociological Review, 65, 19-51.

Keskin, U., \& Sağlam, H. İ. (2014). Sınıf öğretmeni adaylarının insani değerlere sahip olma düzeylerinin çeşitli değişkenler açısından incelenmesi. Sakarya University Journal of Education, 4(1), 81-101.

Mehmedoğlu, U. (2006). Gençlik, değerler ve din: Küreselleşme, ahlak ve değerler. U. Mehmetoğlu \& Y. Mehmetoğlu (Ed.). Küreselleşme, ahlak ve değerler (ss. 54-68). İstanbul: Litera Yayıncılık.

Özensel, E. (2003). Sosyolojik bir olgu olarak değer. Değerler Ĕ̆itim Dergisi, 1(3), 217-239.

Saracaloğlu, A. S., Uça, S., Başara-Baydilek, N., \& Coşkun, N. (2013). Öğretmen adaylarının demokratik tutumları ile değer algilarının incelenmesi. Adnan Menderes Üniversitesi Ĕ̌itim Fakültesi Ĕ̆itim Bilimleri Dergisi, 4(1), 45-59.

Sarı, E. (2005). Öğretmen adaylarının değer tercihleri: Giresun Eğitim Fakültesi örneği. Değerler Eğitim Dergisi, 3(10), 73-88.

Schwartz, S. H. (1992). Universals in the content and structure of values: Theoretical advances and empirical tests in 20 countries. Advances in Experimental Social Psychology, 25(1), 1-65.

Schwartz, S. H. (1994). Are there universal aspects in the structure and contents of human values? Journal of Social Issues, 50(4), $19-45$.

Schwartz, S. H. (2006). A theory of cultural value orientations: Explications and applications. Comparative Sociology, 5, $130-180$.

Şahin-Fırat, N., \& Açıkgöz, K. (2012). Bazı değişkenler açısından öğretmenlerin değer sistemleri. Hacettepe Üniversitesi Ĕ̆itim Fakültesi Dergisi, 43, 422-435.

Şişman, M. (2000). Öğretmenlik mesleğine giriş. Ankara: PegemA Yayıncılık.

Tosun, T., \& Uyanık-Balat, G. (2017). İlkokul birinci sınıfa devam eden çocukları olan annelerin değer algılarının ve çocuklarına aktarmak istedikleri değerlerin karşılaştırmalı incelenmesi. Ĕgitim Kuram ve Uygulama, 13(3), 498-510.

Veugelers, W., \& Vedder, P. (2003). Values in teaching. Teachers and Teaching: Theory and Practice, 9, $377-389$. 
Yalız-Solmaz, D. (2015). Öğretmen adaylarının insani değer düzeyleri: Anadolu Üniversitesi Beden Eğitimi ve Spor Öğretmenliği bölümünde bir araştırma. Uluslararası Sosyal Bilimler Dergisi, 8(41), 1069-1076.

Yazıcı, K. (2006). Değerler eğitimine genel bir bakış. Türklük Bilimi Araştırmaları, 19, 499-522.

Zevalsiz S. (2014). Üniversite öğrencilerinin değer algısı: Karabük Üniversitesi örneği. Turkish Studies -International Periodical for the Languages, Literature and History of Turkish or Turkic, 9(2), 1739-1762. 